\title{
O ENCONTRO ENTRE ESTADO E CIDADÃO: REFLEXÕES TEÓRICAS PRELIMINARES SOBRE A COMUNICAÇÃO COMO RELAÇÃO E RECIPROCIDADE
}

THE MEETING BETWEEN STATE AND CITIZEN: PRELIMINARY THEORETICAL REFLECTIONS ON THE COMMUNICATION AS RELATIONSHIP AND RECIPROCITY

EL ENCUENTRO ENTRE ESTADO Y CIUDADANO: REFLEXIONES TEÓRICAS PRELIMINARES SOBRE LA COMUNICACIÓN COMO RELACIÓN Y RECIPROCIDAD

\author{
Bruno Kegler ${ }^{1}$ \\ Mestrando em Comunicação (UFSM) \\ brunokegler@gmail.com \\ Maria Ivete Trevisan Fossá ${ }^{2}$ \\ Doutora em Administração (UFRGS) e \\ Mestre em Comunicação Social (UMESP) \\ fossa@terra.com.br
}

\begin{abstract}
Resumo: A temática abordada neste estudo é a "comunicação como um encontro", considerada como um possível aporte teórico para o estudo da comunicação pública contemporânea, ou seja, das relações entre Estado e cidadãos. Entendemos que a comunicação pública visa a relação entre o Estado, o governo e a sociedade, com o objetivo de informar os cidadãos sobre os seus direitos e deveres e assim atuar como agentes responsáveis pela manutenção ou transformação da ordem social vigente. A comunicação abordada refere-se à comunicação enquanto relação entre os sujeitos comunicantes, que buscam o encontro com o outro na mensagem para satisfazer seus desejos e necessidades.
\end{abstract}

Palavras-chave: comunicação; comunicação pública, reciprocidade.

\begin{abstract}
The topic addressed in this study is the "communication as a meeting", considered as a possible theoretical contribution to the study of contemporary public communication, i.e. the relations between State and citizen. We believe that public communication aims at the relationship between the State, Government and society, with the objective of informing citizens about their rights and duties and thus act as agents responsible for the maintenance or transformation of the existing social order. The communication addressed refers to communication as a connecting link between the communicating subjects, seeking a meeting with the other in the message to satisfy their wishes and needs.
\end{abstract}

Keywords: communication, public communication, reciprocity. 
Resumen: El asunto abordado en este estudio es la "comucación como un encuentro", considerada como un posible soporte teórico para el estudio de la comunicación pública contemporánea, o sea, de las relaciones entre Estado y ciudadanos. Entendemos que la comunicación pública visa la relación sobre el Estado, el govierno y la sociedad, com objetivo de informar los ciudadanos sobre sus derechos y deveres y así actuar como agentes responsables por la manutención o transformación del orden social vigente. La comunicación abordada hace referencia a la comunicación cuanto relación entre los sujetos hablantes que buscan el encuentro con el otro en el mensaje para satisfacer sus deseos y necesidades.

Palabras-Clave: comunicación; comunicación pública; reciprocidad.

\section{INTRODUÇÃO}

Entendemos que a comunicação pública, assim como a comunicação das organizações privadas e organizações não governamentais, é afetada por um espaço diversificado e midiatizado (SODRÉ, 2002), pela heterogeneidade dos sujeitos receptores das mensagens e por uma infinidade de recursos tecnológicos e de meios de comunicação para comunicar com estes sujeitos. $\mathrm{Na}$ atualidade, comumente se atribui às tecnologias a solução para todos os problemas relativos à falta de comunicação. A cada descoberta, reacende-se a esperança de que haverá mais comunicação.

As pessoas já estão interligadas em tempo integral, através de telefones celulares, computadores pessoais e, principalmente, através da internet. Ainda assim, discutem-se problemas de falta de comunicação. Observamos que há um paradoxo constituído, pois há cada vez mais tecnologias disponíveis, mais informação, porém, há também mais incompreensão entre os sujeitos (WOLTON, 2010). Nunca se teve acesso a tantas informações, mas também nunca as diferençasculturais foram tão visíveis.

O equívoco está em crer que astecnologias resolverão todos os problemas de falta de comunicação e de incompreensão entre os sujeitos. As relações são sociais e os sujeitos são humanos, com toda a complexidade que lhes é particular.Por isto, a relação teórica que propomos é entre as contribuições de Peruzzolo (2006), que aborda a comunicação como um encontro entre os sujeitos; as reflexões de Wolton (2010), que orienta seus estudos a partir das 
motivações que impulsionam os sujeitos à comunicação;e, por fim, as proposições teóricas sobre comunicação pública (ZEMOR, 2009; BRANDÃO, 2007) que vislumbram a comunicação enquanto diálogo entre Estado e cidadãos.

Compreendemos a proposta de Peruzzolo (2006) como bastante rica e adequada ao estudo de comunicação pública, visto que situa a importância do emissor e também do receptor para que haja comunicação, destacando a reciprocidade nesta relação. Assim, consideramos adequado estudar a comunicação pública, pensando-a como um encontro entre instituições públicas e cidadãos, estes os receptores da mensagem, que se põem em relação através desta.

A categoria conceitual proposta por Peruzzolo (2006), assim como a de Wolton (2010), é alternativa às abordagens tecnicistas do conceito de comunicação, que ora se detém apenas no processo comunicativo humano, ora detém-se apenas no aspecto técnico do processo comunicacional, desconsiderando a complexidade e as subjetividades das relações de comunicação. Entendemos que os modelos tecnicistas de comunicação, referenciados pelos autores, tendem a centrar-se no desenvolvimento de técnicas ou tecnologias eficientes para a troca de informações, norteando-se pela concepção unilateral de simples transmissão de informação.

De acordo com Sodré (2002), concepções desta ordem consistem em exaltar as potencialidades do dispositivo técnico, para ocultar os interesses relacionados à manutenção da hegemonia dominante. Em contraponto a estas concepções, Peruzzolo (2006) propõe que pensar a comunicação na sua essência considera a sua força e evita análises quantitativas e superficiais que, ainda que reconheçam a necessidade de interação entre os sujeitos comunicantes, desconsideram o que há de mais primordial, que é o movimento que leva à busca pelo outro e a reciprocidade intrínseca à relação de comunicação.

Diante destas considerações, não pretendemos a negação do desenvolvimento tecnológico e suas influências, ou das análises quantitativas e tecnicistas. Almejamos, através de uma visão crítica e interpretativa proporcionada pela concepção da comunicação enquanto relação, analisar o contexto da comunicação pública contemporânea.

Para chegarmos aos objetivos propostos, partiremos da compreensão da Teoria da Comunicação como Encontro, de Peruzzolo (2006), que, como fio condutor teórico desse estudo, nos guiará na reflexão sobre a comunicação pública contemporânea. A seguir, abordaremos o estudo de Dominique Wolton (2010) e, por fim, a última seção do artigo visa 
compreender as principais noções e características da comunicação pública contemporânea a partir, especialmente, de Brandão (2007), Zémor (2009) e Toro e Werneck (2004), além de relacionar os pressupostos de comunicação pública com a perspectiva da comunicação como encontro apresentada na primeira seção do artigo.

\section{COMPREENDENDO A COMUNICAÇÃO COMO ENCONTRO}

O estudo de Peruzzolo (2006) contempla a comunicação desde os seus primórdios, entendendo-a como uma relação, que é motivada pela procura por respostas aos desejos e necessidades próprios. Por isto a comunicação se torna central nos processos de subjetivação. Segundo o autor, conceber o fenômeno da comunicação desta forma considera a reciprocidade do ato de comunicar, distinguindo-o da simples transmissão de mensagens, que consiste na emissão unilateral de informações. Sobre o modelo de comunicação preconizado, destaca o autor que é formulado a partir de uma rede relacional.

O caráter relacional do processo comunicativo subentende o equilíbrio de forças entre os comunicantes, onde não há sobreposição de um sobre o outro. Assim, descarta-se também a passividade e caracteriza a comunicação como um processo cooperativo entre os comunicantes. O conceito de comunicação proposto coloca a comunicação entre os sujeitos e não nos sujeitos, contemplando a relação entre os comunicantes e os fluxos que vão destes à mensagem.

Peruzzolo (2006) explica que a comunicação é desencadeada pela impulsão pela vida, que é a força motriz que move os sujeitos a estabelecer relações com o outro e com o meio ambiente, situando-a antes mesmo da organização social e caracterizando-se como a força que produz o social. Todo gesto ou fala, enquanto mensagem, leva consigo todo o investimento de desejos e necessidades do sujeito emissor em relação ao outro a quem se dirige. Este, ao perceber a mensagem, fará sua representação e assim caracterizará o estabelecimento da relação. Daí que Peruzzolo (2006) destaca que a comunicação ocorre no encontro entre os sujeitos.

Para que haja a comunicação, a primeira condição é a percepção do outro. Após a percepção, há a representação, que “é o investimento qualitativo no dado percebido. É um processo avaliativo pelo qual os estímulos percebidos recebem valorações, porque passam a 
significar algo para o organismo" (PERUZZOLO, 2006, p.34). A representação é indireta, partindo da percepção de algo, o sujeito fará a avaliação e a atribuição de valores que constituirá sua representação sobre este algo. Desta forma, a percepção e a representação atuam como reguladores das relações estabelecidas pelos indivíduos.

No ser humano, "a representação funcionou nos limiares do simbólico e, desde a aquisição das competências técnicas, [...], sempre esteve ligada ao pensamento simbólico" (PERUZZOLO, 2006, p.35). Desde então, a representação humana, apesar da base biológica, é determinada pela cultura e é condicionada pela ação do indivíduo sobre algo para atender aos seus interesses. Daí que o autor destaca que o objeto percebido deixa de ser puro, pois estará repleto de valorações, que orientarão a conduta do indivíduo que o percebe.

Nem toda relação é uma relação de comunicação. A especificidade desta é a representação da matéria entre os comunicantes, e a qualidade da representação define a comunicação, seja a humana ou a animal. As materializações de toda ordem, são submetidas à representação do outro, que então fará sua interpretação. Assim, a mensagem enquanto meio materializado para o encontro entre os sujeitos, "é um pacote de representações, que serve de ponto de passagem para as significações sociais" (PERUZZOLO, 2006, p.45). Dito assim, a relação de comunicação implica a relação entre os sujeitos envolvidos, entre o emissor e a mensagem e entre o destinatário e a mensagem.

Esta concepção sobre a comunicação, para Peruzzolo (2006), busca entender seu conceito no limiar do cultural, onde ela é apenas um processo relacional. A cultura e o desenvolvimento tecnológico são resultado destas relações, conforme afirma:

(...) a cultura existe apenas através da ação interativa dos membros de uma sociedade; o que significa afirmar que são os processos de interação pessoal que produzem não só os produtos, mas também os sistemas culturais de trocas e intercâmbios, principalmente, as significações, que são as que fazem a afirmação da ou de uma sociedade (PERUZZOLO, 2006, p.180)

Diante disso, somente depois, em meio às complexidades técnicas desenvolvidas pelo homem, a comunicação pode ter intencionalmente seus objetivos desviados da sua função primordial, mas ainda continuará havendo em tudo isso a busca pela relação de comunicação. A capacidade projetiva de representar o futuro que marca o princípio da representação humana, tendo como marco a criação e materialização da pedra lascada. Mais especificamente, pelas simbolizações presentes no seu projeto e no seu emprego, antes mesmo da sua confecção. 
Um exemplo pertinente à reflexão proposta neste estudo é pensar que as tecnologias de comunicação e de informação são resultado da capacidade projetiva humana. A técnica é humana, pois passa pelo projeto, o que está por vir a ser materializado. Assim, a evolução dos próprios meios de comunicação satisfaz a demanda cultural vigente e é ancorada na relação entre máquina, técnica, e homem. São produções que atendem aos objetivos do ser humano.

Em relação à linguagem, o seu desenvolvimento e complexificação também estão relacionados à percepção, à representação e ao controle do código genético. Peruzzolo (2006) referencia três categorias para a linguagem: a imagem, o sinal e o simbólico. A primeira está caracterizada pela imediatidade da relação, em que os próprios comunicantes são a mensagem para o outro. No nível do sinal, não ocorre o encontro entre os sujeitos, mas há uma mediação que representa a presença do outro.

É esta separação que possibilitará o desenvolvimento da linguagem, que será tão desenvolvida quanto a habilidade da espécie permitir, porém tanto em relação à imagem quanto ao sinal, estarão condicionadas pelo programa do código genético. Já para o homem, que é um ser simbólico,

(...) o afastamento entre os comunicantes é amplo, até total e indeterminável, e as relações corpolexpressão, signolreferente e matéria da comunicaçãolsignificado são multissignificantes, arbitrários, ficcionais e eventuais (no sentido de acontecimento, não casuais), não sendo iguais para todos os indivíduos da espécie humana nem precisam ser usados nas mesmas circunstâncias(PERUZZOLO, 2006, p.75).

Deste modo, os objetos em si são neutros de significação, bem como as palavras. O autor explica que o comunicante,ao entrar em relação, atribuirá o valor correspondente ao que significa para ele determinado objeto ou situação. Assim sendo, a mesma palavra desencadeará significações distintas entre uma diversidade de indivíduos. O símbolo, como ordem de representações desenvolvida pelo homem para confrontar-se com a realidade, permite-lhe o afastamento das relações diretas e a ampliação de suas relações indefinidamente, ampliando suas possibilidades de ação. A dimensão humana de mundo é simbólica.

O movimento do ser em direção ao outro para estabelecer relações de comunicação tem em sua origem o desejo de vir a ser (PERUZZOLO, 2006). As representações materializadas em falas, gestos, escrita, pertencem ao plano da linguagem, onde também estão as tecnologias de comunicação. Neste plano surgem as ambigüidades da comunicação devido à ampliação das possibilidades de escolhas, que afasta o ser do controle do código genético. Dito de outra 
forma, a comunicação simbólica sai do plano da sobrevivência para o plano das opções, das escolhas.

Peruzzolo (2006) também descreve que a mediação da comunicação promove o distanciamento do encontro entre os sujeitos, e por ser a busca pelo vir a ser, implica também um distanciamento dos encontros consigo mesmo, daí que a técnica acresce ambigüidade à representação, retardando a relação. Nas palavras do autor, a comunicação humana "ambígua, polivalente e complexa, porque diferida na relação básica do homem com o homem, pela busca e elaboração de extensões criadas para atingir uma comunicação mais densa e mais ampla" (PERUZZOLO, 2006, p.88), tudo isto graças a sua capacidade simbólica.

Sobre este aspecto, os estudos de Edgar Morin (2001) contribuem ao afirmar que a compreensão de si torna possível a compreensão do outro, do diferente, pois permite a superação das próprias carências e, a partir daí, a abertura para conviver com as carências e fraquezas do outro. Explica o autor, que a incompreensão deteriora as relações entre pais e filhos, marido e esposa e entre culturas e credos distintos.

Há aqui um paradoxo, pois nunca se teve acesso a tantas informações e tantos dispositivos técnicos, como o telefone celular e o computador pessoal com câmera integrada, para "aproximar" as pessoas. Porém, a proximidade não representa a compreensão, pelo contrário, pode contribuir para a incompreensão se despertar sentimentos como ciúmes e agressividade.

Esta reflexão permite ratificar que a questão não reside na quantidade de informações, mas na qualidade da comunicação. Como é sabido e inegável, a sociedade está saturada de informações que poderiam contribuir para diminuir a incompreensão entre os ímpares e de meios de comunicação que conectam as pessoas em tempo integral. Porém, a questão não reside aí, na aproximação pela técnica ou na quantidade de informações, mas sim na motivação que poderia levar às pessoas a buscarem informações para derrubar seus preconceitos, para conviver com o diferente, e até que ponto as relações mediadas podem substituir o contato presencial e atenuar os conflitos existenciais.

A proposta desta teoria é afastar o conceito de comunicação da idéia de transmissão de informações, entendendo-a como uma relação que entre os comunicantes pode fazer-se por meio de uma transmissão. Assim, a reciprocidade intrínseca à comunicação está na natureza da proposta, ou seja, "a mensagem organizada é, primeiramente, resposta à necessidade e ao desejo do outro para necessidade e desejo próprios" (PERUZZOLO, 2006, p.97). 
A força da mensagem é determinada pela qualidade de resposta à necessidade de seu intercomunicante. $\mathrm{O}$ autor destaca que a comunicação nunca será simples transmissão ou transposição de informação de um sujeito para o outro, por isto que a relação ocorre entre os comunicantes, na cooperação mútua entre eles. Daí que há o princípio da igualdade na relação e remete à natureza altruísta dos fenômenos sociais. Pensar a comunicação por seu caráter recíproco permite dizer que a individualidade dos sujeitos jamais será transmitida, pois o encontro ocorre no agenciamento entre os sujeitos.

A condição básica da comunicação é a reciprocidade, que compreende não apenas a necessidade do outro para a realização de si, mas é também a condição que impulsiona o ser à busca pelo encontro com o outro para fazer-se homem. Evidencia-se a sociabilidade do ato de comunicar e a importância das relações com a alteridade para o encontro consigo, pois a relação de comunicação se torna a própria fonte de satisfação dos desejos e necessidades dos sujeitos envolvidos. Isto nos leva a sublinhar o agenciamento entre os sujeitos, que é o compartilhamento de onde eles extrairão algo para ser diferente daquilo que eram quando entraram na relação, evidenciando a interdependência intrínseca à relação de comunicação.

Ao entender a comunicação diferente da simples transmissão de mensagens e da relação estímulo e resposta, levamos em conta a complexidade da relação em direção ao encontro com o outro, a interdependência, o compartilhamento e a justaposição entre os comunicantes na relação, compreendemos a comunicação como ato social e em seu caráter primordial de constituição do ser a partir da construção da sua subjetividade. E, as reflexões de Peruzzolo (2006) apresentadas até aqui, nos dão subsídios para orientarmos nossas idéias acerca da comunicação, especialmente a comunicação pública, que é o objeto de interesse neste estudo. A compreensão das particularidades da comunicação humana e das motivações que levam os sujeitos a buscar estabelecer relações, especialmente de comunicação, é fundamental para situarmos a distinção entre o que é relativo à técnica e o que é humano, e entre o que é informação e o que é comunicação.

\section{O PARADOXO DA "IN" COMUNICAÇÃO CONTEMPORÂNEA EM REDE}

A proposta de Wolton (2010) é consonante com a de Peruzzolo (2006), ao pensar a comunicação de uma maneira alternativa às visões tecnicistas. $\mathrm{O}$ autor descreve que tais 
abordagens escondem as dificuldades e os insucessos da comunicação humana e, por isto, pretende "destecnologizar" a comunicação, situando o lugar da informação neste processo.

Wolton (2010) comenta que há, na atualidade, uma distorção quanto aos significados de informação e de comunicação. Enquanto esta é vista sob desconfiança, associada à persuasão e à manipulação, a informação é tida como mais confiável. Diante desta afirmação, destaca que não se pode pôr informação e comunicação em lados opostos, pois estão intimamente relacionadas. Para diferenciá-las, enumera três razões que permitem ver a maior complexidade da comunicação.

Primeiro, para que haja a comunicação, é necessário que estejam em sintonia os sujeitos da relação. Segundo, é contraditório associar a comunicação à manipulação, pois nunca se investiu tanto tempo e dinheiro em tecnologias com a finalidade de permitir a comunicação. Por fim, a informação faz parte de um projeto de comunicação. Deste modo, afirma que "a informação é a mensagem. A comunicação é a relação, que é muito mais complexa" (WOLTON, 2010, p.12).

O autor também destaca que os problemas de falta de comunicação não são resultado da falta de informação, mas das diferenças entre os sujeitos, da incompreensão com o outro, com o diferente. É neste sentido que orienta suas reflexões, propondo repensar a comunicação, num momento em que muito se discute as potencialidades comunicativas e informativas das tecnologias dominantes.

Por isto, argumenta que a revolução do século XXI não é a da informação, mas da comunicação, das resistências impostas pela diversidade de receptores à relação de comunicação. Tal dificuldade é fruto dos filtros criados pelos sujeitos diante da saturação de mensagens que competem por sua atenção, que atuam no sentido de negar o diferente e fazer ver sua opinião, seu próprio ponto de vista. Diante deste processo, a relação torna cada vez mais evidente a importância da negociação na comunicação.

A ênfase na presença do outro sujeito, receptor da relação de comunicação, ilustra a afirmação de que a quantidade de informações não é o único fator determinante para que haja mais comunicação. Como descreve Dominique Wolton

(...) com tecnologias limitadas, as mensagens trocadas envolviam públicos mais homogêneos. Hoje, as mensagens são incontáveis, as tecnologias, quase perfeitas, e os receptores sempre mais numerosos, heterogêneos e reticentes. Isto não decorre apenas da diversidade de línguas, mas também das representações, culturas e visões de mundo que se entrechocam (WOLTON, 2010, p.16). 
$\mathrm{Na}$ verdade, na proposta apresentada pelo autor, a diversidade emergente de informações e de opiniões, possibilitada pela comunicação em rede, contribui para que haja mais incompreensão, na medida em que todas as diferenças se tornam visíveis e se entrechocam. Ao reforçar, que pensar a comunicação a partir do receptor e das resistências que este impõe ao emissor, permite a superação da idéia de comunicação como transmissão de informações, para pensá-la a partir das negociações que se estabelecem nas relações de comunicação. Peruzzolo (2006) concorda ao afirmar que a relação ocorre entre os comunicantes, num processo de cooperação mútua entre eles agenciada.

Por tudo isso que referenciamos, Wolton (2010) enumera cinco etapas inerentes à Teoria da Comunicação defendida por ele, aplicada para as relações face a face e mediadas tecnologicamente. Primeiro, comunicar é uma necessidade humana vital. Segundo, são três razões que motivam o desejo de buscar a comunicação: compartilhar, convencer e seduzir. Terceiro, há as resistências impostas pelo receptor, sejam elas por falta de sintonia ou mesmo pela discordância. Quarto, a negociação estabelecida para buscar um acordo. Por fim, o quinto chama-se de convivência, que é o saldo positivo resultante da negociação (WOLTON, 2010).

Em relação a estas etapas, também é possível identificar pontos convergentes com a teoria de Peruzzolo (2006), a qual reconhece a comunicação como resultado do impulso pela vida; enfatiza a importância do receptor, colocando-o em condições de igualdade na relação, sem haver a sobreposição de um sujeito intercomunicante sobre o outro; e, por fim, salienta o agenciamento entre os sujeitos, que é o compartilhamento de onde se extrai algum acréscimo da relação para ser diferente daquilo que eram quando entraram na relação.

Dominique Wolton (2010) aborda a questão da incompreensão e destaca a necessidade da negociação para que haja a convivência pacífica e salutar entre os sujeitos e também entre as sociedades, reduzindo-se a incompreensão e a intolerância. A ênfase na relação, colocandose os sujeitos em igualdade de condições no processo de negociação, caracteriza uma abordagem humanista, como define Wolton (2010), opondo-se às teorias funcionalistas, que têm como foco as potencialidades técnicas dos dispositivos tecnológicos para a resolução dos problemas de falta de comunicação. Também é uma concepção de caráter político, na medida em que sublinha a necessidade de negociar para atenuar as divergências de pontos de vista e atuar democraticamente.

A relação estabelecida entre comunicação e democracia, acentua a necessidade da negociação, tendo em vista que esta é fundamental à democracia, não com o intuito de 
eliminar as diferenças, mas de assentá-las para a convivência pacífica e salutar entre os sujeitos.

Diante do contexto atual, em que a sociedade se encontra permeada pela comunicação em rede, Dominique Wolton aponta duas ideologias que "ameaçam a comunicação: o individualismo, ou seja, a redução da comunicação à expressão e à interatividade, e o comunitarismo, isto é, a marginalização da questão da alteridade e a possibilidade do encerramento em espaços virtuais (2010, p.24)." Entendemos que a questão levantada pelo autor, revela a preocupação quanto à virtualização das relações sociais, que são convertidas em fluxos de informação, em detrimento das relações face a face. $\mathrm{O}$ encontro virtual com o outro implica na possibilidade de construção de um "eu" próprio à relação que busco estabelecer, orientando minhas ações e falas.

Em consonância, Muniz Sodré (2002) assinala que há, na atualidade, a sensação de que tempo e espaço são virtualmente eliminados, devido à instantaneidade da distribuição de informações. E Castells (1999) propõe que o espaço organiza o tempo na sociedade em rede, a partir da lógica que denomina de "espaços de fluxos", que constitui a "cidade informacional" e que se opõe à lógica historicamente reconhecida: "espaço de lugares". De acordo com a sua proposição, diversos serviços, que denomina de avançados, podem ser reduzidos a fluxos de informação, ou seja, podem, através das telecomunicações e da informática, realizar-se em qualquer lugar do globo terrestre. A cidade informacional está cada vez mais vinculada através das redes, e menos pela proximidade espacial.

Não só os serviços, mas as instituições públicas, privadas e os indivíduos também são convertidos em representações virtuais, através dos fluxos de informação da comunicação virtual. Conforme Sodré, nos dias de hoje, a sociedade é regida "pela tendência à "virtualização" ou "telerrealização" das relações humanas, presente na articulação do múltiplo funcionamento institucional e de determinadas pautas individuais de conduta com as tecnologias de comunicação" (2002, p.21). Cria-se a sensação de proximidade e de presença, devido à instantaneidade da distribuição de informações, porém, por trás disto, há o afastamento dos sujeitos, que tendem a se relacionar cada vez mais através de contatos virtuais e com representações construídas pelos próprios sujeitos que, ao contrário dos encontros presenciais, podem não ser fidedignas à realidade.

A possibilidade de tornar visível a própria opinião, em âmbito global, não significa que haverá mais negociação entre opiniões antagônicas, pois depende do uso que se faz das 
tecnologias disponíveis. Se o sujeito não estiver aberto à negociação, não haverá comunicação.

Outro aspecto relevante salientado por Wolton (2010) refere-se ao surgimento de novas formas de associações e vínculos comunitários, também em ambientes virtuais, porém com características distintas das formas tradicionais de associação. A principal diferença é a sua transitoriedade, devido à fragilidade dos laços sociais, que podem ser desfeitos a qualquer tempo, em questão de segundos. A este respeito, Dominique Wolton afirma que

(...) o laço social dizia respeito às relações sociais e culturais relativamente estáveis. Hoje, é quase o oposto, tudo estando em interação. Os processos de informação e de comunicação contribuem para estruturar, por meio das múltiplas interações, um novo espaço público baseado num vínculo social mais dinâmico e frágil (WOLTON, 2010, p.25).

Repensar a comunicação em torno do conceito de convivência contribui para a reflexão sobre os laços sociais nos dias de hoje. Sobre isto, o autor assinala que há, na atualidade,outra distorção do sentido de informação e de comunicação. Enquanto que a primeira, está tradicionalmente associada a algo novo que vem a abalar as estruturas vigentes, a segunda está associada à idéia de vínculo, de compartilhamento.

$\mathrm{Na}$ atualidade, esta perspectiva é alterada, pois a informação passa a estabelecer o vínculo, devido a sua centralidade nas relações sociais e à confiança que os sujeitos têm nela. Já a comunicação, tem seu significado deslocado de reunião, de compartilhamento, para convivência, visando a assentar os antagonismos emergentes.

Em suma, a crítica de Wolton (2010) às ideologias tecnicistas, indica que comumente se atribui, nestas abordagens, um poder às tecnologias que não lhes compete, que são funções e responsabilidades do ser humano, principalmente as relacionadas aos problemas enfrentados individualmente e em sociedade, relativos à comunicação, às relações sociais e à manutenção ou transformação da ordem social.

Por esta perspectiva, há uma distorção do significado de alguns termos, atribuindo-se às tecnologias a capacidade de transformação de uma realidade social, subordinando o homem à técnica, ou seja, invertendo-se a lógica. Exemplos desta confusão de sentidos estão em falar de "civilização e de sociedade digital, sociedade da informação, democracia digital ou sociedade em rede" (WOLTON, 2010, p.30). Assim atribui-se aos avanços tecnológicos o avanço da comunicação e da compreensão humana, o que é um equívoco. 
Wolton (2010) não nega que as tecnologias de comunicação possam, sim, contribuir para melhorar a comunicação, pois atuam no sentido de reduzir a "incomunicação", o que no nosso entendimento, consiste em eliminar ruídos e aperfeiçoar a transmissão de informações. Porém, a dificuldade está em tentar atribuir esta qualidade das tecnologias de informação à comunicação humana, desconsiderando a complexidade dos sujeitos envolvidos na relação. Compreendemos que, ao invés de "maquinizar" o homem e suas relações, deve-se buscar o que propõe o autor, “destecnologizar” a comunicação.

A reflexão do autor aponta para a dependência tecnológica que, na contemporaneidade, assola boa parte das pessoas, em diversos pontos do Globo Terrestre, processo que resulta na tendência à virtualização das relações sociais. Isto tudo porque o telefone celular, o computador e a internet, principalmente, incorporaram-se ao cotidiano e são quase que inseparáveis da rotina diária dessas pessoas.

Tudo isso contribui para compreendermos o aspecto paradoxal das tecnologias de comunicação, relativo ao conflito entre "dominação" e "libertação". No passado, as tecnologias contribuíram para o movimento de emancipação, "libertação de todas as dependências externas (religiosas, políticas...)" (WOLTON, 2010, p.31). A contradição reside em aceitar a subordinação às tecnologias, que outrora foram importantes ferramentas libertárias.

Segundo o autor, a dependência descrita passa despercebida, entranhada nas possibilidades interativas, multimídia e instantâneas da internet. Porém, enquanto são exaltadas as suas possibilidades libertárias, de produção e distribuição de opiniões e conteúdos, acesso "ilimitado" às informações, multiplicidade de fontes de informações e a horizontalidade da comunicação, o tempo livre das pessoas vai sendo consumido, preenchido pela interação com a máquina e por relações virtuais, parcela do dia que antes era destinado às associações, à leitura, à vida em sociedade, à família, etc. As relações virtuais não substituem os encontros presenciais, pois "somos seres sociais, não seres da informação" (WOLTON, 2010. p. 34).

Mas e como pensar então a influência da revolução tecnológica na comunicação pública? Como a compreensão da complexidade que envolve a comunicação humana pode contribuir para a comunicação entre as instituições públicas e os cidadãos? Como esta relação pode afetar a comunicação entre políticos e cidadãos? Pode haver, através da internet, uma ampliação da participação dos cidadãos nas deliberações sobre interesses de assunto coletivo? 
Pode, a internet, contribuir para a democracia? Pode servir a internet para o estabelecimento do diálogo com os cidadãos? Não pretendemos encontrar respostas definitivas, mas discutir a base teórica para posteriormente aprofundarmos investigações com o intuito de responder a estes questionamentos. É esta a nossa proposta para a próxima parte do nosso estudo.

\section{COMUNICAÇÃO PÚBLICA CONTEMPORÂNEA E DEMOCRACIA}

Para Brandão (2007), ainda não há uma definição para o conceito de comunicação pública. Dentre as diversas abordagens, a autora destaca que há em comum o entendimento que "diz respeito a um processo comunicativo que se instaura entre o Estado, o governo e a sociedade com o objetivo de informar para a construção da cidadania" (BRANDÃO, 2007, p.9), sendo este o significado que prevalece nos estudos acadêmicos, no Brasil.

O significado de "cidadão" compreendido neste estudo "é a pessoa capaz de criar ou transformar, com os outros, a ordem social, a quem cabe cumprir e proteger as leis que ele mesmo ajudou a criar" (TORO e WERNECK, 2004, p.21). Sendo assim, o exercício da cidadania não se restringe ao voto, mas engloba a responsabilidade de atuar na manutenção, construção ou transformação de uma ordem social. Essa atuação tem sido exaltada em discursos acadêmicos e profissionais diante da potencialidade tecnológica em proporcionar o diálogo. Ressaltamos, no entanto, o cuidado para que não haja a valorização do meio em detrimento do seu uso social, visto que a tecnologia por si só, não é capaz de impulsionar práticas mais cidadãs e democráticas.

O conceito de cidadania tem, na atualidade, seu sentido alterado, passando a ser "apreendida como o livre exercício de direitos e deveres, situação para a qual só se está preparado quando existem condições de informação e comunicação" (BRANDÃO, 2007, p.10). Desta forma, a comunicação tem papel político fundamental para a formação da cidadania e o aprofundamento da democracia.

Brandão (2007) afirma também, que a expressão “comunicação pública” tem sido comumente associada apenas à comunicação dos órgãos governamentais, substituindo outras denominações que designavam a comunicação dos governos, como comunicação governamental e comunicação política. Tal fato, busca particularizar a comunicação desenvolvida pelo Estado ou pelo governo, na atualidade, aproximando-a do conceito de democracia, para evitar confusões com a comunicação desenvolvida em outras épocas no 
país, associadas à idéia de persuasão e manipulação, como marketing político e propaganda política. Entendemos que a especificação do termo é resultado das transformações ocorridas nas últimas décadas, que levaram à restauração da democracia e à necessidade de ações voltadas a estimular o exercício da cidadania.

Desde 1988, com a Constituição Brasileira, a democracia está assegurada no artigo primeiro e tem a cidadania como um de seus fundamentos. Toro e Werneck (2004) destacam que a democracia, em seu sentido pleno, passa pela conscientização de todos os sujeitos, pertencentes a uma coletividade, de que o destino da sociedade está em suas mãos. Sendo assim, toda ordem social é resultado da vontade e das escolhas dos homens, constituindo-se num processo em constante construção e passível de mudanças.

Esta compreensão também permite entender que, assim como o homem é responsável pela construção da ordem, também é pelo caos, fruto da sua inércia e da sua indiferença. Além disto, é possível caracterizar a centralidade da comunicação e das relações sociais no processo de engajamento cívico coletivo, e a necessidade de diálogo dos representantes públicos com o cidadão, ouvindo as demandas e oferecendo as informações solicitadas.

A relação que embasa a pertinência entre a teoria da comunicação como encontro (PERUZZOLO, 2006) e os pressupostos de comunicação pública, situa-se em nossa investigação, na ênfase dada ao processo participativo, relacional e dialógico, das duas perspectivas. Como propõe Brandão (2007), relativo à comunicação pública, a própria noção de cidadania transforma esta área da comunicação, pois “começa a ser entendida de forma menos passiva e mais participativa, apreendida como o livre exercício de direitos e deveres, situação para a qual só se está preparado quando existem condições de informações e comunicação" (BRANDÃO, 2007, p.10).

Daí que para falar em democracia, deve-se pensar a necessidade de haver, no interior da sociedade, interesse de negociação entre representantes políticos e cidadãos, além de espaços próprios para isto. Refletindo sobre a comunicação pela internet, Wolton (2010) descreve que alguns políticos buscaram a comunicação com os cidadãos via blogs, caracterizando a substituição da complexidade humana pela interação virtual. Deste modo, descreve que "a internet não poderá ser o novo motor da democracia, pois a questão do poder não se resume à informação, mas diz respeito a valores e à comunicação entre seres humanos" (WOLTON, 2010, p.43). A compreensão deste processo, pelo autor, atribui à internet o poder de informar, sem promover o diálogo. 
Ainda que reconheça que há relações entre os sujeitos envolvidos, entendemos que o seu posicionamento aponta para a interferência da mediação tecnológica nestas relações, que tendem a influenciar, em maior ou menor grau, a construção de mensagens e, consequientemente, as representações envolvidas no encontro entre os sujeitos. Nossa afirmação fundamenta-se nas possibilidades de edição de conteúdos e de construção de uma representação do eu, algo que não pode ser possível nos encontros pessoais.

Toro e Werneck (2004) enumeram quatro princípios da democracia. O primeiro é o da autofundação, ou seja, numa democracia a própria sociedade cria sua ordem social e suas leis, diretamente ou indiretamente, através dos representantes eleitos pelo voto. É um processo que exige aprendizado e a sua assimilação é primordial para a convivência democrática. $\mathrm{O}$ segundo é o princípio da cosmovisão, que consiste em ver cada pessoa como capaz de criar ordem social. O terceiro é o princípio da incerteza, que revela que não há um modelo pronto de democracia, pois é um processo, em constante construção. O quarto, o princípio do público, descreve que a democracia não pressupõe a ausência de diferenças, de conflitos, mas está na capacidade da sociedade de assentar as diferenças em prol do interesse coletivo. Assim, aquilo que é público, que interessa a todos, é construído e se fortalece na sociedade civil.

Desta percepção, compreende-se o respeito às instituições públicas, pois, representam os interesses de todos os setores da sociedade. Além disto, o processo democrático não visa à eliminação das diferenças, mas a tolerância e a compreensão para que haja uma convivência pacífica entre os cidadãos. Por fim, reforça-se a necessidade do diálogo e da negociação entre o Estado e os cidadãos, para que estes se mobilizem e sejam agentes responsáveis pela manutenção ou transformação da ordem social vigente.

Para as organizações privadas, Henry Jenkins (2009) assinala que estão sendo desenvolvidas ações publicitárias para sensibilizar os consumidores a permanecer mais tempo em contato com a marca, nos diversos suportes de mídia ou na conjunção entre diferentes tipos de mídia dentro de um site, por exemplo. Esta estratégia é denominada pelo autor de extensão de marca e torna a mensagem o próprio objeto de consumo. Neste processo, há a valorização da estética e o uso de recursos que permitem contatos diversificados, como jogos eletrônicos, enquetes, vídeos, almanaques digitais, etc. Porém, a exemplo da competição do mercado, pautada pela venda de produtos, a transformação da mensagem em objeto de 
consumo, possibilita que ela seja descartada assim que não atender mais às expectativas dos consumidores ou quando um concorrente apresentar um "produto" melhor.

Já para a comunicação pública, entendemos que não podem ser adotadas as mesmas estratégias. Tornando-se objeto de consumo, também será descartável. Há a necessidade de uma adequação ao contexto midiatizado, apropriando-se das tecnologias disponíveis, porém sem perder a sua essência, que está em atender ao interesse dos cidadãos, em ações continuadas e perenes, interessantes por seu conteúdo cognitivo. Para Brandão (2007) a comunicação pública é integrante da vida social e política.

(...) ela não é um poder em si, mas o resultado do poder do cidadão quando organizado e constituído como sociedade civil. A comunicação pública feita pelos governos, pelo terceiro setor ou pelas empresas privadas acontece na medida em que a voz do cidadão começa a ficar forte a ponto de pressionar essas instituições a se preocupar com as questões da cidadania. (BRANDÃO, 2007, p. 30-31).

Neste caso, é pertinente ser pautada pela relação já existente ente cidadão e instituição, ou seja, o conteúdo já terá o objetivo de atender uma demanda apresentada pelo cidadão. Para Zemor (2009), na comunicação pública, o cidadão não pode ser comparado a um consumidor, por isto ela não deve ser apropriar de técnicas de marketing. $\mathrm{O}$ autor prega o afastamento das características concorrenciais do mercado e a busca do diálogo com a sociedade, prestando informações de utilidade pública para que as pessoas se sintam inseridas na relação e a mensagem permaneça.

\section{CONSIDERAÇÕES FINAIS}

A opção pela proposta de Peruzzolo (2006) nos permite pensar a comunicação em sua essência, distinguindo-a de informação e afastando-a da idéia de simples transmissão de mensagens, para compreendê-la como uma relação complexa, que ocorre entre os sujeitos que se põem em relação em igualdade de condições num processo de cooperação mútua. Pela reciprocidade intrínseca à relação, é necessária a troca entre os sujeitos, resultado do agenciamento entre eles na mensagem e de onde obterão algum ganho que atenderá aos desejos e necessidades que o impulsionaram à relação.

No mesmo sentido, a Teoria defendida por Wolton (2010) propõe pensar a comunicação a partir do receptor e das resistências que este impõe ao emissor, salientando a necessidade de 
negociação entre os sujeitos na relação. Partindo deste princípio, a questão não reside na falta de informação e a discussão não deve estar centrada nas potencialidades técnicas dos meios de comunicação, mas deve atentar à negociação para conviver pacificamente com as diferenças.

O desafio proposto neste estudo foi compreender pressupostos teóricos preliminares para investigar a comunicação pública, entendida inicialmente como processo comunicativo entre o Estado e a sociedade, com a finalidade de informar para a construção da cidadania (BRANDÃO, 2007). Diante da reflexão teórica realizada, entendemos que o vir a ser da comunicação pública é "comunicar para a construção da cidadania”.

Como vimos nas propostas de Peruzzolo (2006) e Wolton (2010), a questão a ser discutida não é a informação, mas a falta de comunicação, observando-se as subjetividades dos sujeitos intercomunicantes. Esta carência traz como resultado a incompreensão com o outro, com as diferenças que nunca estiveram tão visíveis.

Esta realidade a informação não pode transformar, nem as novas tecnologias de comunicação, pois como sublinhamos no decorrer deste estudo, a comunicação é humana e as relações são sociais. Sendo assim, não se pode atribuir à informação, o papel da comunicação. Nem às tecnologias o que é de responsabilidade do homem, pois não existe uma onipotência tecnológica. Daí que situar o fenômeno da comunicação é essencial para evitar distorções entre os significados dos termos.

Diante deste contexto, entendemos que para a comunicação pública, aplicam-se os mesmos princípios. O Estado precisa buscar a relação continuada com os cidadãos, para estabelecer relações sólidas e perenes. Como destaca Peruzzolo (2006), tem que haver a troca, e a reciprocidade é intrínseca à relação de comunicação. Por isto a construção da cidadania não passa apenas pelo fornecimento de informações, pois só elas não mobilizarão os sujeitos a assumirem sua responsabilidade de manutenção ou transformação da ordem social. Há que se considerar a complexidade dos sujeitos e a importância do agenciamento na relação de comunicação, aspectos essenciais para se pensar a cidadania.

Por outro lado, a sociedade encontra-se permeada pelas tecnologias de comunicação e, assim como os indivíduos, as instituições públicas, organizações privadas e o Estado também são afetados por estas transformações. Portanto, não se trata de negá-las, mas também não se pode atribuí-las a capacidade de resolver problemas de ordem social e humana. Trata-se, 
então, do uso que delas se faz e da compreensão de como podem ser empregadas para melhorar a comunicação pública, diante da necessidade do diálogo e da negociação.

Ações isoladas, especialmente na internet, que não se originem do diálogo com os cidadãos, não serão respostas às suas expectativas e caracterizarão ações unilaterais de transmissão de informações. O Estado, enquanto sujeito comunicante da comunicação pública, precisa estabelecer relações de comunicação com a sociedade para informar aquilo que é resposta aos desejos e necessidades dos cidadãos.

Observados estes aspectos, a criação de um site na internet pode ser um importante meio de comunicação entre o Estado e a sociedade, desde que haja o interesse mútuo. Deste modo, as informações serão respostas às demandas dos cidadãos, atendendo às suas expectativas e, assim, estabelecendo, efetivamente, comunicação.

\section{REFERÊNCIAS}

BRANDÃO, Elizabeth Pazito. Conceito de comunicação pública. In: DUARTE, Jorge. Comunicação pública: estado, mercado, sociedade e interesse público. São Paulo: Atlas, 2007.

CASTELLS, Manuel. A sociedade em rede: a era da informação: economia, sociedade e cultura. São Paulo: Paz e Terra, 1999.

JENKINS, Henry. A cultura da Convergência. São Paulo: Aleph, 2009.

MORIN, Edgar. Os sete Saberes Necessários à Educação do Futuro. 3a ed. São Paulo Cortez; Brasília, DF: UNESCO, 2001.

PERUZZOLO, Adair. A comunicação como encontro. Bauru, SP: Edusc, 2006.

SODRÉ, Muniz. Antropológica do Espelho. Por uma teoria da comunicaçãolinear e em rede. Petrópolis, RJ: Vozes, 2002.

TORO, Jose Bernardo; WERNECK, Nisia Maria Duarte. Mobilização social - um modo de construir a democracia e a participação. Belo Horizonte: Autêntica, 2004.

WOLTON, Dominique. Informar não é comunicar. Tradução de Juremir Machado da Silva. Porto Alegre: Sulina, 2010.

Post sobre a Palestra "Comunicação Pública: a Experiência Francesa. 24 de abril de 2009. Brasília, DF, 2009. In: http://carlosscomazzon.wordpress.com/2009/04/29/para-especialistascomunicacao-publica-prioriza-cidadao/ Acesso em 19 nov, 2010. 
Original recebido em: 26/05/2011

Aceito para publicação em: 29/11/2011

\section{Resumo sobre os autores:}

1 Bruno Kegler é mestrando em Comunicação (UFSM/2010); Membro do Grupo de Pesquisa Comunicação Institucional e Organizacional/CNPq; Professor Colaborador da UNIJUÍ; Especialista em Marketing e Recursos Humanos pela Faculdade Metodista de Santa Maria (2007); Graduado em Comunicação Social - Habilitação Publicidade e Propaganda pela Universidade Federal de Santa Maria (2006).

http://buscatextual.cnpq.br/buscatextual/visualizacv.do?id=K4480906J1

2 Maria Ivete Trevisan Fossá possui graduação em Comunicação Social - Habilitação Relações Públicas pela Universidade Federal de Santa Maria (1978), graduação em Administração pela Universidade Federal de Santa Maria (1980), especialização em Formação de Professores de Disciplinas Especializa pela Universidade Federal de Santa Maria (1981), mestrado em Comunicação Social pela Universidade Metodista de São Paulo (1997) e doutorado em Administração pela Universidade Federal do Rio Grande do Sul (2003). Atualmente é Professor Adjunto da Universidade Federal de Santa Maria, Membro de corpo editorial da Formas e Linguagens (UNIJUÍ), Membro de corpo editorial da Cadernos de Comunicação (UFSM) e Membro de corpo editorial da Revista Brasileira de Gestão de Negócios (São Paulo). Tem experiência na área de Comunicação , com ênfase em Relações Públicas e Propaganda. Atuando principalmente nos seguintes temas: cultura organizacional, comunicação organizacional, organização do trabalho, recursos humanos, comprometimento organizacional.

http://buscatextual.cnpq.br/buscatextual/visualizacv.do?id=K4704310P1 